\title{
Degradation of Petroleum Refinery Waste by A Consortium of Hydrocarbonoclastic Bacteria Cultured on Combinations Of Medium C:N:P Ratio
}

\author{
Syukria I. Zam ${ }^{1 *}$ and Irfan Mustafa ${ }^{2}$ \\ ${ }^{1}$ Faculty of Agriculture and Husbandry, UIN Sultan Syarif Kasim, Riau \\ ${ }^{2}$ Biology Department, Faculty of Sciences, Brawijaya University, Malang
}

\begin{abstract}
Bioremediation is an alternative method to treat petroleum waste using microorganism into nontoxic end product. The method is relatively cheap, effective, and environmental friendly. A key factor influencing bioremediation process for petroleum refinery waste treatment is C:N:P ratio of bacterial growth medium. The objective of this research was to obtain C:N:P ratio of Stone Mineral Salt Solution (SMSS) medium that allow optimal degradation of petroleum refinery waste by consortium of hydrocarbonoclastic bacteria. C:N:P ratio of SMSS medium was adjusted to ratio of 100:10:1, 100:10:0.5, 100:5:1, and 100:5:0.5. We demonstrate that optimal degradation of petroleum refinery waste by a consortium of hydrocarbonoclastic bacteria was achieved in SMSS medium with C:N:P ratio of 100:5:1. It allowed $66.55 \%$ degradation of total petroleum hydrocarbon (TPH) and $85.18 \%$ decrease of chemical oxygen demand (COD) value.
\end{abstract}

Keywords: bioremediation, C:N:P ratio, hydrocarbonoclastic bacteria

\section{INTRODUCTION}

Bacteria that have ability to degrade hydrocarbon compound are termed as hydrocarbonoclastic bacteria [1]. Naturally, they can bind, emulsify, transport, and degrade hydrocarbon compound.The hydrocarbonnoclastic bacteria degrade hydrocarbon compound by excising hydrocarbon chain to make it shorter, involving some specific enzymes. The synthesis of those enzymes is coded by bacterial chromosome or plasmid depending on the type of the bacteria [2].

The biodegradation of hydrocarbon compound originated from petroleum refinery waste is affected by biological and physicochemical factors. The biological factors cover the nature and quantity of the bacteria and availability of the bacterial enzymes. Physicochemical factors which affect bacterial degradation of hydrocarbon compound are the composition, chemical structure and concentration of hydrocarbon, temperature, oxygen availability, salinity, $\mathrm{pH}$, nutrition, light, and osmotic pressure $[3,4]$.

Petroleum is a great source of carbon while it is deficient on nitrogen and phosphor. Such condition leads to the availability of both

\footnotetext{
*Corresponding address:

Syukria I. Zam

Faculty of Agriculture and Husbandry,

UIN Sultan Syarif Kasim, Riau

Indonesia

Email: siz.pku@gmail.com
}

elements becomes the limiting factor on hydrocarbon degradation by hydrocarbon-clastic bacteria. The ratio adjustment of C:N:P by adding urea, NPK fertilizer, ammonium salt, and phosphate salt could optimize bacterial capacity on hydrocarbon degradation. Therefore, this research aimed to obtain the C:N:P ratio that support optimal degradation of petroleum refinery waste by hydrocarbonoclastic bacteria [4].

\section{MATERIALS AND METHODS}

\section{Bacterial consortium and combination of $\mathrm{C}: \mathrm{N}: \mathrm{P}$ ratio}

Petroleum refinery waste was obtained from Bengkalis, Riau Province in Indonesia. It was a black colored and flammable liquid. Ten species of hydrocarbonoclastic bacteria which were isolated previously from the same petroleum refinery waste were applied on this work as a consortium. They were Acinetobacter baumannii, Alcaligenes eutrophus, Bacillus cereus,Bacillus sp1., Bacillus sp2., Flavobacterium ranchiophiia, Methylococcus capsulatus, Morococcus sp., Pseudomonas diminuta, and Xanthomonas albilineans. To support bacterial growth, the Stone Mineral Salt Solution (SMSS) was used as a minimum medium which was consists 5.0 grams of $\mathrm{CaCO}_{3} ; 2.5$ grams of $\mathrm{NH}_{4} \mathrm{NO}_{3} ; 1.0$ gram of $\mathrm{Na}_{2} \mathrm{HPO}_{4} .7 \mathrm{H}_{2} \mathrm{O} ; 0.5$ gram of $\mathrm{KH}_{2} \mathrm{PO}_{4} ; 0.5$ gram of $\mathrm{MgSO}_{4} .7 \mathrm{H}_{2} \mathrm{O} ; 0.2$ gram $\mathrm{MnCl}_{2} .7 \mathrm{H}_{2} \mathrm{O}$; and $1 \%$ yeast extract per liter. The final $\mathrm{pH}$ was 
adjusted to 6.5 [5]. The medium was supplemented with $50 \% \quad(\mathrm{v} / \mathrm{v})$ petroleum refinery waste as $\mathrm{C}$ source and combinations of $\mathrm{NH}_{4} \mathrm{NO}_{3}$ and superphosphate fertilizer (SP36)as $\mathrm{N}$ and $\mathrm{P}$ source that fall into four C:N:P ratios. The ratio combinations are 100:10:1 $(100 \mathrm{~mL}$ petroleum refinery waste, $3.52 \mathrm{~g} \mathrm{NH}_{4} \mathrm{NO}_{3}, 0.34$ g SP36), 100:10:0.5 (100 mL petroleum refinery waste, $3.52 \mathrm{~g} \mathrm{NH}_{4} \mathrm{NO}_{3}, 0.17 \mathrm{~g} \mathrm{SP36),} \mathrm{100:5:1}$ $(100 \mathrm{~mL}$ petroleum refinery waste, $1.76 \mathrm{~g}$ $\left.\mathrm{NH}_{4} \mathrm{NO}_{3}, 0.34 \mathrm{~g} \mathrm{SP36}\right)$, and 100:5:0.5 (100 mL petroleum refinery waste, $1.76 \mathrm{~g} \mathrm{NH}_{4} \mathrm{NO}_{3}, 0.17$ g SP36) [6].

\section{Culturing bacterial consortium in media with various $C: N: P$ ratio}

Each bacterial species was cultured separately in SMSS medium supplemented with 10\% (v/v) petroleum refinery waste and incubated at room temperature with agitation $120 \mathrm{rpm}$ until exponential growth reached. Afterward, they were mixed together on equal cell density and transferred, as much as $10 \%(\mathrm{v} / \mathrm{v})$, to SMSS medium with four combinations of C:N:P ratio in $500 \mathrm{~mL}$ conical flask. The consortium were incubated at room temperature with agitation $120 \mathrm{rpm}$ for seven days. Every twenty-four hours, a total plate count was performed to provide the bacterial growth curve. On the initial and last day of incubation period the TPH and COD level were evaluated.

\section{TPH and COD analysis}

Total petroleum hydrocarbon analysis of the petroleum refinery waste from each culture was performed using Gravimetric method before and after incubation period. Five milliliter petroleum sample was extracted with5 $\mathrm{mL}$ benzene, pentane, and diethylether (3:1:1). The petroleum was then weighed to get the amount of petroleum contained in the sample. Degradation level was detected by calculating the ratio of initial TPH subtracted by final TPH and the initial TPH [7]. Chemical oxygen demand level was detected to examine the total chemical substance concentration in the waste before and after incubation period. It was performed regarding to Dichromate Reflux Technique Standard Method. Twenty five milliliters sample was transferred to $500 \mathrm{~mL}$ conical flask. Add 1.0 gram $\mathrm{HgSO}_{4}$ and $5.0 \mathrm{~mL}$ concentrated $\mathrm{H}_{2} \mathrm{SO}_{4}$ into the conical flask and stir-dissolved. Add $12.5 \mathrm{~mL}$ of $0.25 \mathrm{~N} \mathrm{~K}_{2} \mathrm{Cr}_{2} \mathrm{O}_{7}$ slowly to get homogenous solution. During stirring process,
$35 \mathrm{~mL}$ of concentrated $\mathrm{H}_{2} \mathrm{SO}_{4}$ was added. The solution was refluxed for 2 hours and cooled down. Aquadest was added to get the total volume of $175 \mathrm{~mL}$. Then 2-3 drops of Ferroin indicator was added and titrated with FAS $[\mathrm{Fe}$ $\left.\left(\mathrm{NH}_{4}\right)_{2}\left(\mathrm{SO}_{4}\right)_{2}\right]$ until the color changed to brownish red. The value of COD was calculated using the formula according to Horwitz (2000) [8].

\section{RESULTS AND DISSCUSION}

The optimal C:N:P ratio for petroleum biodegradation process was around 100:10:1 [6]. Furthermore, we examined four combination of $\mathrm{C}: \mathrm{N}: \mathrm{P}$ ratio which were 100:10:1, 100:10:0.5, 100:5:1, and 100:5:0.5 in SMSS medium. Considered parameters on deciding the optimal degradation of petroleum refinery waste were bacterial growth rate, level of TPH degradation and COD reduction. Based on our result, combination of C:N:P ratio at 100:5:1 provided the highest value of TPH degradation and COD reduction which were $66.55 \%$ and $85.18 \%$, respectively (Figure 1). Figure 2 shows bacterial growth curves between four combination of $\mathrm{C}: \mathrm{N}: \mathrm{P}$ ratio and the 100:5:1 ratio provide better exponential growth than others with the growth rate was 0.0457 cell per hour (data not shown). The result suggest that such condition is an optimal ratio of C:N:P elements for hydrocarbonoclastic bacteria to grow and degrade petroleum optimally. This correspond to Leahy and Colwell (1990)[4] which stated that appropriate comparison of nutrients, especially nitrogen and phosphor are main critical factors to improve petroleum degradation level. Addition of nitrogen and phosphor can increase the respiration rate of bacterial cell. It amplified the amount of energy production which lead to improvement of hydrocarbon degradation. Besides, C:N:P ratio is one of limiting factors in bioremediation process [9]. The original comparison of the ratio was very dependent on the waste characteristics, so an appropriate comparison of nutrients will give an optimal bioremediation result.

The study showed that C:N ratio at 100:5 has better bacterial growth and biodegradation result compared to that at 100:10. Metabolism of high nitrogen concentration resulted in high nitrite formation. It was a toxic compound that disturbed the bacterial growth and the biodegradation process. Hydrocarbon degradation and bacterial growth were stimulated by nitrogen addition [10]. Nitrogen compound in a significant amount can suppress 
bacterial growth. A suitable nitrogen level was necessary to avoid the present of toxic compounds [11].



Figure 1. A growth curve of bacterial consortium in SMSS media supplemented with $50 \%$ petroleum refinery waste at combinations of C:N:P ratio.

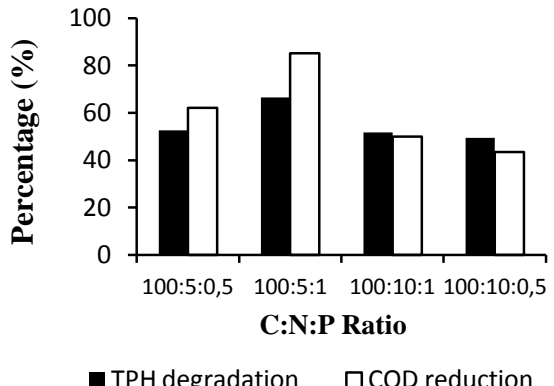

Figure 2. TPH degradation and COD reduction level by bacterial consortium in SMSS media supplemented with 50\% petroleum waste at combinations of C:N:P ratio.

In Figure 2, it indicates that $\mathrm{C}: \mathrm{N}: \mathrm{P}$ ratio at 100:5:1 supported degradation of petroleum refinery waste and reduction of COD level significantly compared to other ratios. A balanced C:N:P ratio will allow optimal bacterial growth and degradation of hydrocarbon and non-hydrocarbon compound resulting in reduction of COD level. Nitrogen is necessary for protein synthesis, while phosphor source is necessary for DNA, RNA, and ATP synthesis $[12,13]$. Protein, DNA, RNA, and ATP are important molecules in cells. If those molecules are present in optimal amount, bacterial growth and ability to degrade petroleum waste will improve. An adequate $\mathrm{C}: \mathrm{N}: \mathrm{P}$ ratio could increase the biosurfactant production. The presence of biosurfactant could increase petroleum waste solubility in water and widen the contact between bacteria and petroleum waste. It resulted in improving the biodegradation process. According to Kinbal (1994)[14], surfactant serve to widen the contact surface between hydrocarbon and bacteria through micelle formation thus improve hydrocarbon solubilization and emulsification.

\section{CONCLUSIONS}

Based on the study, we conclude that the ratio of C:N:P at 100:5:1 was optimal condition for bacterial consortium to degrade Bengkalis petroleum refinery waste. The condition resulted in $66.55 \%$ decrease of TPH level, $85.18 \%$ reduction of COD level with growth rate of hydrocarbonoclastic bacterial consortium was 0.0457 cell per hour.

\section{REFERENCES}

[1] Davis, J.B., 1967, Petroleum Microbiology, Elsevier Publishing Co., Amsterdam.

[2] Ashok, B. T., Saxena, S., Susarrat, J., 1995, Isolation and Characterization of Four Polycyclic Aromatic Hydrocarbon Degrading Bacteria from Soil Near on Oil Refinery, Letter in Applied Microbiology. The Society for Aplied Bacteriology, 21, 246 - 248.

[3] Atlas, R. M., and Bartha, R. 1992. Microbial Ecology, Benyamin Cummings Science, California.

[4] Leahy, J. G., and Colwell, R. R., 1990, Microbial Degradation of Hydrocarbons in The Environment.. Microbiol. Rev, 54, 305 - 315.

[5] Sharpley, J. M., 1966, Elementary Petroleum Microbiology, Gult, Publ. Co, Texas.

[6] Cookson, W., 1995, Bioremidiation Engeenering, Mc Graw-Hill, New York.

[7] Pikoli, M. R., 2000, Isolasi Bertahap Bakteri Termofilik Pendegradasi Minyak Bumi dari Sumur Bangko, Tesis Magister Biologi Institut Teknologi Bandung, Bandung.

[8] Horwitz, W., 2000, Official Methods of Analysis of Aoac International. $17^{\text {th }}$ edition, AOAC.

[9] Afif, S.M., 2006, Treatment of OBM Drill Cutting Soil by Elimination of Biodegradation Limiting Factors Using Bio-augmented Land Farming. The Annual International Conference on Contaminated Soils, Sediments, and Water, Massachusetts.

[10] Wrenn, B. A., Haines, J. R., Venosa, A. D., Kadkhodayan, M., and Suidan, M. T., 1994, Effects of Nitrogen Source on Crude Oil Biodegradation. J. Ind. Microbiol, 13, 279 - 286. 
[11] Mulvey, P., 2002, Treatment, Recovery and Disposal Technology: Bioremediation Techniques for Petroleum Facilities, Environmental and Earth Sciences Pty Ltd., North Sydney.

[12]Black, J., 1999, Microbiology Principles and Explorations, Prentice Hall Upper Saddle River, New Jersey.
[13] Moat, A. G., and Foster, J. W, 1995, Microbial Physiology 3th edition, John Wiley and Sons Inc, Publication, New York.

[14] Kinbal, S. L., 1994, The Use of Surfactans to Enhance Pump and Treat Processes for In Situ Soil Remidiation, Remidiation of Hazardous Waste Contaminated Soil, Marcell Dekker, Inc. New York. 